\title{
Statistical evaluation and predicting the possible sources of particulate matter in a Mediterranean metropolitan city
}

\author{
Summak G. ${ }^{1}$, Ozdemir H. ${ }^{2,}{ }^{*}$, Oruc I. ${ }^{3}$, Kuzu L. ${ }^{1}$, Saral A. ${ }^{1}$ and Demir G. ${ }^{4}$ \\ ${ }^{1}$ Environmental Engineering Department, Civil Engineering Faculty, Yildiz Technical University, Istanbul, Turkey \\ ${ }^{2}$ Istanbul Technical University, Ayazaga Kampusu, Maslak 34469, Istanbul, Turkey \\ ${ }^{3}$ Vocational College of Technical Sciences, Kirklareli University, Kirklareli, Turkey \\ ${ }^{4}$ Urban and Regional Planning Department, Architecture Faculty, Kirklareli University, Kirklareli, Turkey \\ Received: 28/04/2017, Accepted: 27/11/2017, Available online: 06/12/2017 \\ *to whom all correspondence should be addressed: e-mail: ozdemirhuseyin@itu.edu.tr
}

\begin{abstract}
In Mega-cities, such as Istanbul, urbanization causes heavy traffic. Air pollution, which originated from heavy traffic and industrialization, is one of the most important problems for the people who live in the populated cities. Due to both environmental and health effects, particulate matter problem always remains popular and serves an important research field. For this purpose, $\mathrm{PM}_{2.5}$ and $\mathrm{PM}_{10}$ measurements were taken in the megacity of Istanbul, close to Besiktas district by a low volume sampler at 5 different sampling stations. A total of 150 samples, 75 samples of $\mathrm{PM}_{2.5}$ and 75 samples of $\mathrm{PM}_{10}$ were collected from these sampling stations. Sampling period was between March 2009 and March 2010. Determination of particulate matter concentration was performed by the gravimetric method and elemental concentrations were analyzed with Inductively Coupled Plasma (ICP-OES). Principal Component Analysis (PCA) and Enrichment Factor (EF) analysis were applied to obtained elemental concentrations in order to identify the possible sources associated with the particulate matter. Four factors for $\mathrm{PM}_{2.5}$ and five factors for $\mathrm{PM}_{10}$ were determined by PCA method, which had variance contributions of $82.3 \%$ for $\mathrm{PM}_{2.5}$ and $83.5 \%$ for $\mathrm{PM}_{10}$. Acquired data showed that Istanbul ambient air was dominated by traffic emissions and crustal originated elements.
\end{abstract}

Keywords: particulate matter, $\mathrm{PM}_{2.5}, \mathrm{PM}_{10}$, elemental concentrations, PCA, EF

\section{Introduction}

Within the last century, PM (particulate matter) emissions originated from anthropogenic sources have increased drastically and correspondingly it resulted in negative effects on human health, visibility decrease in urban and rural areas, acid deposition, and deterioration of the radiation balance of the world (Wang et al., 2005; Seinfeld and Pandis, 2006; Koçak et al., 2009). Particulate matter structure is so complex that each component of a particle structure is hard to determine. However, according to studies that were performed so far, the most abundant composition of the aerosols has been observed to be sulfate, ammonium nitrate, sodium, chloride, trace metals, carbonaceous substances, crustal elements and water droplets (Seinfeld and Pandis, 2006).

Particulate matter can either be emitted from natural or anthropogenic sources directly and can occur at the atmosphere as secondary particulates (Finlayson-Pitts and Pitts, 1986; WHO, 2013). Particulate matter can be characterized by their physical attributes that influence their transportation and deposition, and their chemical composition that influences their effect on health (Cheremisinoff, 2002). The concentration, composition, and particle size of suspended particulate matter in a sampling site are identified by such factors as meteorological conditions of the atmosphere, topographical influences, emission sources, and by particle's own properties such as density, shape, and hygroscopicity (Fang et al., 2003).

In recent years, an increase on PM is being observed due to their hazardous health effects on human health and the negative effects on the environment, the ecosystem, and the climate (IPCC, 2001; WHO, 2003). There are diverse effects of PM on human health, but the most dangerous and remarkable one is the effect on the respiratory system of particles (Hetland et al., 2004). According to the assessment of WHO (World Health Organization) about air pollution related diseases, the premature birth of 2 million deaths occur each year and its cause is considered to be urban indoor and outdoor air pollution generated from combustion of solid fuels (WHO, 2007). Additionally, it was reported that exposure to ambient particulate matter causes adverse health effects such as increased mortality, hospitalization for respiratory or cardiovascular disease, respiratory symptoms and decreased lung function (Fang et al., 2003). Epidemiological studies have revealed that there is a significant relation between the ambient air concentrations of fine particulate matter and mortality and morbidity (Samara and Voutsa, 2005). By taking this situation into account, it was stated that chemical characterization and sources apportionment for $\mathrm{PM}_{2.5}$ were more useful for assessing health risk of air pollution and 
planning effective control measures (Young and Wang, 2002). Due to this fact, particulate matter composition and health effects were investigated by several researchers in either ambient air or indoor air (D'Alessandroa et al., 2003; Shah and Shaheen, 2007; Yatkin and Bayram, 2007; Merešová et al., 2008; Colombi et al., 2013).

There are previous studies related to airborne particulate matter (Samura et al., 2003; Yatkin and Bayram, 2007; Koçak et al., 2009). In another study conducted in Besiktas, the sampling locations of this study, size segregated particulate matter composition was determined in terms of ions and metals and two prevailing particulate modes were found throughout $\mathrm{PM}_{10}$ (Kuzu et al., 2013). Excessive $\mathrm{Cd}$ and $\mathrm{Ni}$ concentrations were observed in that study. Also, two major particle modes were found to be present in the Istanbul atmosphere. The fine mode which was between 0.43 and $1.10 \mu \mathrm{m}$ was of traffic origin, whereas the coarse mode which was between 5.80 and $9.00 \mu \mathrm{m}$ originated from the mechanical abrasion of the road pavement. Another contribution was from marine aerosol.

Srimuruganandam et al. (2011) analyzed the chemical characterization of $\mathrm{PM}_{10}$ and $\mathrm{PM}_{2.5}$ mass concentrations emitted by heterogeneous traffic in Chennai city during monsoon, winter and summer seasons. It was reported that 24-h averages of $\mathrm{PM}_{10}$ and $\mathrm{PM}_{2.5}$ mass concentrations, showed higher concentrations during the winter season $\left(\mathrm{PM}_{10}=98 \mu \mathrm{g} / \mathrm{m}^{3} ; \quad \mathrm{PM}_{2.5}=74 \mu \mathrm{g} / \mathrm{m}^{3}\right)$ followed by the monsoon $\left(\mathrm{PM}_{10}=87 \mu \mathrm{g} / \mathrm{m}^{3} ; \mathrm{PM}_{2.5}=56 \mu \mathrm{g} / \mathrm{m}^{3}\right)$ and summer $\left(\mathrm{PM}_{10}=77 \mu \mathrm{g} / \mathrm{m}^{3} ; \mathrm{PM}_{2.5}=67 \mu \mathrm{g} / \mathrm{m}^{3}\right.$ ) seasons. Chemical composition characterization results showed the dominance of crustal elements ( $\mathrm{Ca}, \mathrm{Mg}, \mathrm{Al}, \mathrm{Fe}$ and $\mathrm{K}$ ), followed by marine aerosols ( $\mathrm{Na}$ and $\mathrm{K}$ ) and trace elements ( $\mathrm{Zn}, \mathrm{Ba}, \mathrm{Be}, \mathrm{Ca}, \mathrm{Cd}, \mathrm{Co}, \mathrm{Cr}, \mathrm{Cu}, \mathrm{Mn}, \mathrm{Ni}, \mathrm{Pb}, \mathrm{Se}, \mathrm{Sr}$ and $\mathrm{Te}$ ) emitted from road traffic in both $\mathrm{PM}_{10}$ and $\mathrm{PM}_{2.5}$ mass.

Statistical methods are commonly used in the atmospheric sciences, and specifically PCA allows us to estimate the possible sources of the air pollutants in the atmosphere, especially for particle pollutants. PCA was applied to PM $_{10}$ data, which were collected in Northern Spain and seven sources were identified for three different grain size fractions (Viana et al., 2006). Determination of enrichment factor (EF) for elements in aerosols are important to evaluate anthropogenic versus natural sources (Wang et al., 2005).

Millions of people spend their free time for walking or free physical exercise in public parks (Kesavachandran et al., 2015). There is an emerging contention between the benefits of outdoor activities and detrimental effects of air pollution (Giles and Koehle, 2014). The most vulnerable fractions of the population to air pollution are infants, children and elderly people. This study was designed to be conducted at playgrounds and public parks. These areas are the places where the most sensitive part of the public spends their time at outdoor conditions. Thus, sampling in such areas remains fundamental and their source determination is crucial. The aim of this study is a) to determine the ambient particulate matter concentrations $\left(\mathrm{PM}_{2.5}\right.$ and $\left.\mathrm{PM}_{10}\right)$ with their elemental composition, b) to identify possible sources of particles with the aid of the
PCA , c) to classify the sources as natural or anthropogenic using the enrichment factor in the selected playgrounds in Istanbul.

\section{Materials and methods}

\subsection{Study Area and Measurement Periods}

Istanbul is the most populous and economically important city in Turkey. In addition, Istanbul, as a mega-city, is the cultural and financial center of Turkey. The climate of the city is Mediterranean with warm/dry summers and cold/wet winters. City is located in northwestern area of Turkey $\left(41^{\circ} \mathrm{N}\right.$ and $\left.29^{\circ} \mathrm{E}\right)$ and the city is divided into two parts by Bosphorus Strait. The pollution issue along the Bosphorus is due to both traffic jam on paved roads and dense marine transportation traffic. Additionally, unplanned urbanization, the gradual decrease of green areas and the construction of high-rise buildings negatively affect the circulation of the air in some areas of Istanbul. Hence, between the months of October and March (the coldest months), the city is exposed to high air pollution (Ozdemir et al., 2010).

In this study, ambient particulate matter was collected from five sampling stations in order to investigate the elemental composition. Another feature of the sampling stations is to be playgrounds. Sampling locations were chosen as: (P1) with high-traffic on a main street in the city (Barbaros Boulevard, Besiktas), (P2) the effect of the Bosphorus and close to the Istanbul Strait (Kabatas), (P3) the edge of the O-1 highway with dense traffic (Abide-i Hurriyet Park, Okmeydani), (P4) in a forestry area, it is not affected directly from traffic (Yildiz Park, Besiktas) and (P5) dense residential areas (Abbasaga Park, Besiktas). Study site (Figure 1) is a densely populated area in the central part of Istanbul, where the traffic congestion generally occurs, and also very close to our laboratory, where the elemental analysis was carried out.

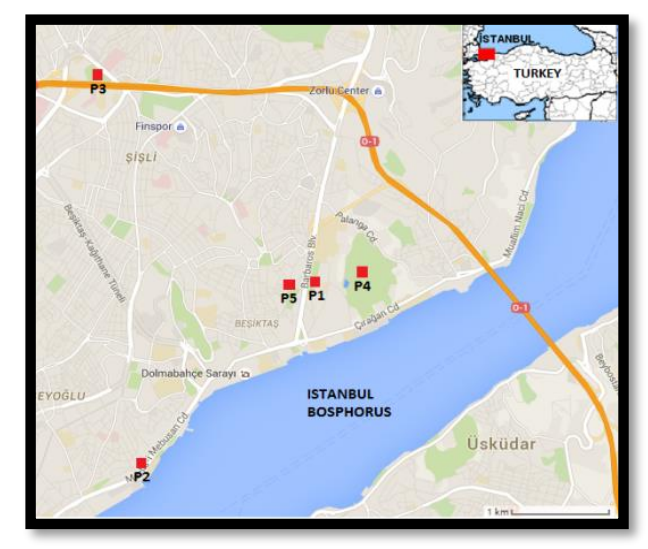

Figure 1. Sampling stations

\subsection{Sampling procedure and chemical analysis}

This study was conducted with one sampling device at five different stations. The device stayed 18 days in one station and when the sampling is completed, it was moved to another sampling location. This cycle took 90 months, which makes one season. Therefore, variation of 
concentration and composition of particles could be revealed for each season in one-year period. In this study, measurements were taken of March 1, 2009 and March 1, 2010.

Particulate matter was collected by a low volume sampler, "Zambelli ISO PLUS 6000" at $1 \mathrm{~m}^{3} / \mathrm{h}$ flow rate. Sampling duration was 24 hours and samples were collected 6 days in a week. Due to the property of the sampling device, only one fraction could be collected at each sampling campaign. $\mathrm{PM}_{2.5}$ and $\mathrm{PM}_{10}$ were collected on two sequential days within the week.

Sampling procedure was applied according to "EPA 40 CFR PART 50" standards. Filters were conditioned for 24 hours before and after the sampling. Laboratory blank and field blank samples were taken for each playground. Sampling analysis procedures were repeated for these blank samples.

A microwave digestion procedure was applied to the particulate matter collected filters. Detailed digestion procedure was reported elsewhere (Demir et al., 2010). After extraction of the filters, elemental concentrations of $\mathrm{Al}, \mathrm{Na}, \mathrm{K}, \mathrm{Ca}, \mathrm{Mg}, \mathrm{Pb}, \mathrm{Cu}, \mathrm{Cr}, \mathrm{Co}, \mathrm{Zn}, \mathrm{Ni}, \mathrm{Cd}$ and $\mathrm{V}$ associated with $\mathrm{PM}_{2.5}$ and $\mathrm{PM}_{10}$ were analyzed by Inductively Coupled Plasma-Optical Emission Spectrometer (ICP-OES, Perkin Elmer Inc.).

\section{Results and discussion}

\subsection{Ambient Concentrations}

Mass concentrations and their variation of $\mathrm{PM}_{2.5}$ and $\mathrm{PM}_{10}$ were given in Figure 2. Mid-line within the box represents the median values and lower and upper lines of the box give the $25^{\text {th }}$ percentile and $75^{\text {th }}$ percentile value. The whiskers at the top and bottom of the boxes represent maximum and minimum observed values, respectively. Detailed assessment of $\mathrm{PM}_{2.5}$ and $\mathrm{PM}_{10}$ mass concentration were reported and discussed in Ozdemir et al., (2010). Thus, PM mass was not discussed explicitly in this study.

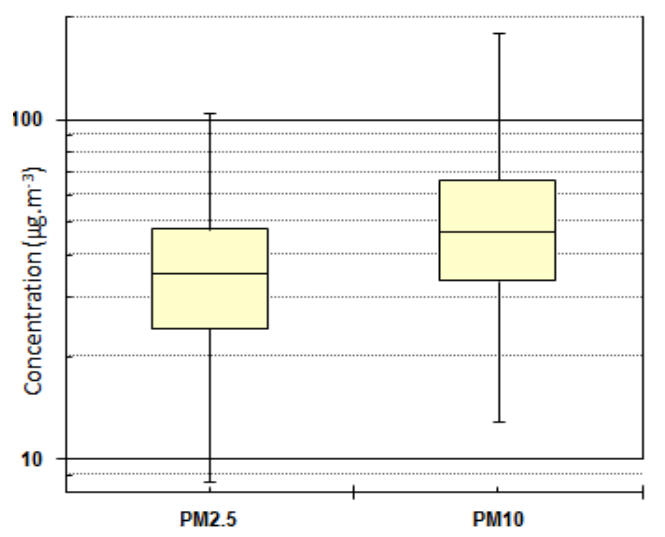

Figure 2. Particulate matter mass concentration variations

Elemental compositions of $\mathrm{PM}_{2.5}$ and $\mathrm{PM}_{10}$ for each of the sampling stations were given in Table 1 and Table 2, respectively.

Table 1. Seasonal variations and average concentrations of elemental composition at five selected sample stations for $\mathrm{PM}_{2.5}\left(\mathrm{ng} / \mathrm{m}^{3}\right)$

\begin{tabular}{|c|c|c|c|c|c|c|c|c|c|c|c|c|c|c|}
\hline Station & Season & Al & $\mathrm{Na}$ & $\mathbf{K}$ & $\mathrm{Ca}$ & $\mathrm{Mg}$ & $\mathrm{Pb}$ & $\mathrm{Cu}$ & $\mathrm{Cr}$ & Co & $\mathrm{Zn}$ & $\mathrm{Ni}$ & Cd & V \\
\hline & Spring & 229.9 & 1081.8 & 371.3 & 822.1 & 160 & 35.3 & 88.7 & 26.3 & 15.4 & 66.8 & 23 & 11.5 & 23.9 \\
\hline P1 & Summer & 422.9 & 799.1 & 229.2 & 790.3 & 168.4 & 23.9 & 58.5 & 6.5 & 1.3 & 58.1 & 4.4 & 1.1 & 15.5 \\
\hline \multirow[t]{3}{*}{$n=15$} & Autumn & 224.1 & 888.3 & 133.3 & 1110.7 & 169.3 & 6.7 & 34.3 & 4.3 & 0.3 & 39 & 2.6 & - & - \\
\hline & Winter & 255.2 & 382.4 & 378.1 & 1488.4 & 116.1 & 16.9 & 27.6 & 9.9 & 1 & 85.5 & 10.1 & 0.6 & 10.6 \\
\hline & Spring & 340.1 & 1220.9 & 533 & 961 & 141.5 & 44.5 & 75 & 11.5 & 7.5 & 68.1 & 23 & 7.9 & 44.9 \\
\hline \multirow{4}{*}{$\begin{array}{c}\text { P2 } \\
n=15\end{array}$} & Summer & 283.2 & 1214.5 & 267.6 & 973.6 & 229.7 & 22.1 & 54 & 3.9 & 1.4 & 33.9 & 12.4 & 0.9 & 27.3 \\
\hline & Autumn & 136.9 & 402.6 & 202.3 & 367.2 & 62.2 & 9.5 & 22.9 & 2.2 & 0.1 & 47.2 & 12 & - & 38.6 \\
\hline & Winter & 422.9 & 504.2 & 407.1 & 1175 & 221.4 & 16.4 & 57.4 & 7.9 & 0.1 & 45.6 & 11 & 0.8 & 15.9 \\
\hline & Spring & 1014.3 & 2134.8 & 687.4 & 866.4 & 127.2 & 22.9 & 123.4 & 7 & 0.8 & 89.8 & 10.8 & - & 6.4 \\
\hline \multirow{4}{*}{$\begin{array}{c}\text { P3 } \\
n=15\end{array}$} & Summer & 211 & 1447.9 & 578 & 950.9 & 200.3 & 26.7 & 74.6 & 4.4 & 5.1 & 69.7 & 4.5 & - & 4.4 \\
\hline & Autumn & 713.3 & 594.1 & 701.7 & 1106 & 186.5 & 19.9 & 59.9 & 6.1 & 1.9 & 129.9 & 14.5 & 1.2 & 22.7 \\
\hline & Winter & 418.5 & 257.3 & 456.3 & 661.2 & 43.7 & 27.3 & 48.8 & 2.8 & - & 74.3 & 27.7 & - & 3.2 \\
\hline & Spring & 540.1 & 1955.2 & 369.4 & 786.4 & 113.5 & 11 & 83.9 & 9.2 & 0.5 & 55 & 12.4 & 4 & 5.8 \\
\hline \multirow{4}{*}{$\begin{array}{c}\text { P4 } \\
n=15\end{array}$} & Summer & 85.3 & 3047.2 & 352.1 & 639 & 113.1 & 19.1 & 51.9 & 2.6 & - & 22.9 & 1.7 & 0.9 & 0.4 \\
\hline & Autumn & 60.4 & 322.2 & 140.6 & 296.2 & 29.3 & 34.4 & 8.8 & 0.8 & 0.5 & 62.9 & 3.1 & 0.7 & 9.1 \\
\hline & Winter & 110.9 & 417.4 & 176 & 735.1 & 65.1 & 8.2 & 23.6 & 1.1 & - & 28.5 & 4.4 & - & 7.2 \\
\hline & Spring & 1009.7 & 1655.5 & 658.3 & 1685.7 & 310.8 & 22.5 & 76 & 19.3 & 8.4 & 93.8 & 12.4 & 1.5 & 13.3 \\
\hline \multirow{3}{*}{$\begin{array}{c}\text { P5 } \\
n=15\end{array}$} & Summer & 152.2 & 720 & 294.7 & 564 & 121.7 & 22 & 50.3 & 2.8 & 2.3 & 28.7 & 4.1 & - & 1.7 \\
\hline & Autumn & 33.5 & 359 & 610.2 & 215.7 & 43 & 57.3 & 32.8 & 2.9 & - & 109.4 & 11.9 & 1.8 & 28.3 \\
\hline & Winter & 543.8 & 433.6 & 509.1 & 653.8 & 121.6 & 41.7 & 29.8 & 1.7 & - & 95.8 & 17.3 & - & 21.1 \\
\hline \multicolumn{2}{|c|}{ Average } & 360.4 & 991.9 & 402.7 & 842.4 & 137.2 & 24.4 & 54.1 & 6.6 & 3.1 & 65.2 & 11.1 & 2.7 & 15.8 \\
\hline
\end{tabular}


Table 2. Seasonal variations and average concentrations of elemental composition at five selected sample stations for $\mathrm{PM}_{10}$ $\left(\mathrm{ng} / \mathrm{m}^{3}\right)$

\begin{tabular}{|c|c|c|c|c|c|c|c|c|c|c|c|c|c|c|}
\hline Station & Season & Al & $\mathrm{Na}$ & $K$ & $\mathrm{Ca}$ & $\mathrm{Mg}$ & $\mathrm{Pb}$ & $\mathrm{Cu}$ & $\mathrm{Cr}$ & Co & $\mathrm{Zn}$ & $\mathbf{N i}$ & $\mathrm{Cd}$ & $\mathbf{V}$ \\
\hline & Spring & 2149.3 & 1957.3 & 927.7 & 4407.3 & 777.7 & 60.2 & 102.9 & 30.4 & 16.3 & 96.6 & 22.1 & 12.4 & 19.9 \\
\hline P1 & Summer & 798.3 & 1123.5 & 390.3 & 1773 & 300.3 & 27.3 & 100.9 & 11.7 & 1.2 & 107.2 & 5.9 & 1.5 & 10.3 \\
\hline \multirow[t]{3}{*}{$n=15$} & Autumn & 599.9 & 940.9 & 269 & 1270.5 & 312.5 & 13 & 78.3 & 10.3 & 0.6 & 49.4 & 5 & - & 5.1 \\
\hline & Winter & 583.4 & 364.4 & 952.1 & 1325 & 226.3 & 22.7 & 44.9 & 9.1 & 1 & 120 & 37.2 & 1 & 12 \\
\hline & Spring & 1233.7 & 3095 & 517.8 & 2512.3 & 332.9 & 159.8 & 111.6 & 12.9 & 6.4 & 140 & 15.5 & 15.5 & 22.4 \\
\hline \multirow{4}{*}{$\begin{array}{c}P 2 \\
n=15\end{array}$} & Summer & 730.3 & 2178.4 & 569.6 & 1918.8 & 470.9 & 37.5 & 78.5 & 9.1 & 1.6 & 127.7 & 18.2 & 1 & 43.2 \\
\hline & Autumn & 748.8 & 1430 & 471.1 & 2419.2 & 396.7 & 25.1 & 91.4 & 11.6 & 0.7 & 143.7 & 22.7 & - & 38.1 \\
\hline & Winter & 793.3 & 1343.8 & 682 & 1837.9 & 396 & 36.5 & 80.7 & 9.3 & 0.2 & 133.8 & 14.2 & 1.5 & 27.7 \\
\hline & Spring & 2217.2 & 5734.2 & 1632.1 & 8748.7 & 854.8 & 69.1 & 188.3 & 13.3 & 8.9 & 227.2 & 18.2 & 1 & 29.9 \\
\hline \multirow{4}{*}{$\begin{array}{c}\text { P3 } \\
n=15\end{array}$} & Summer & 714.3 & 2058.6 & 566.3 & 2451.6 & 343.5 & 30.4 & 75.9 & 5.8 & 10 & 45.6 & 6.1 & - & 2.9 \\
\hline & Autumn & 1321.9 & 712.2 & 926.9 & 3588 & 520.3 & 24.4 & 121.4 & 17.8 & 6.6 & 237.7 & 19.8 & 1.7 & 29.2 \\
\hline & Winter & 718 & 1574.6 & 674.1 & 1520.1 & 271.3 & 25.4 & 107.8 & 6.5 & 1.9 & 140.9 & 27.2 & - & 7.9 \\
\hline & Spring & 848.7 & 1240.1 & 270.3 & 997.3 & 148.7 & 26 & 98.4 & 11.8 & 4.3 & 111.9 & 16.3 & 2.9 & 22.6 \\
\hline \multirow{4}{*}{$\begin{array}{c}\text { P4 } \\
n=15\end{array}$} & Summer & 220.7 & 1393.7 & 339.2 & 943.1 & 204.3 & 15.9 & 54.7 & 3.3 & - & 26.9 & 2.7 & 0.9 & 1.3 \\
\hline & Autumn & 79.4 & 626.1 & 173.9 & 1115.1 & 82.8 & 7.3 & 7.9 & 0.9 & - & 36 & 3.5 & 0.4 & 3.3 \\
\hline & Winter & 196.7 & 1051.4 & 280.1 & 1005 & 143.7 & 11.9 & 51.8 & 2 & - & 41.5 & 27 & - & 9.6 \\
\hline & Spring & 905.3 & 1439.2 & 532.6 & 1810.4 & 294 & 36.7 & 97.1 & 19.2 & 3.6 & 131.4 & 13.7 & 15 & 20.7 \\
\hline \multirow{3}{*}{$\begin{array}{c}\text { P5 } \\
n=15\end{array}$} & Summer & 401.6 & 1029 & 396.6 & 1220.9 & 222.1 & 25.9 & 67.5 & 5.3 & 2.8 & 42.2 & 10.6 & 0.1 & 2.2 \\
\hline & Autumn & 480.8 & 491.1 & 693.8 & 1435.8 & 197.5 & 66.7 & 71 & 7.2 & 0.6 & 150.6 & 13.4 & 2 & 26.9 \\
\hline & Winter & 681.5 & 829.7 & 425.2 & 1305.1 & 293 & 17.5 & 36.8 & 2.9 & - & 74.2 & 12.5 & - & 19.3 \\
\hline \multicolumn{2}{|c|}{ Average } & 821.1 & 1530.6 & 584.5 & 2180.2 & 339.4 & 36.9 & 83.3 & 10.0 & 4.1 & 109.2 & 15.5 & 4.0 & 17.7 \\
\hline
\end{tabular}

Considering the results of elemental analysis of the measurements, $\mathrm{Cd}$ values were detected to be between 0.1 and $15.5 \mathrm{ng} / \mathrm{m}^{3}$. Especially, in spring, maximum $\mathrm{Cd}$ concentrations were observed in P1, P2 and P5. The World Health Organization recommends that the concentration of cadmium in the air should be at $1-5 \mathrm{ng} / \mathrm{m}^{3}$ concentration range in rural areas to protect the human health, and it should not exceed $10-20 \mathrm{ng} / \mathrm{m}^{3}$ urban and industrial areas (RSHC, 2010). According to this proposed limit level, measurement results did not reach health hazard level. However, changes in the number of pollutant sources and meteorological factors could shift the concentration range into limit in an exceeding manner.

$\mathrm{Pb}$ values at the sample stations were observed to vary between $6.7-159.8 \mathrm{ng} / \mathrm{m}^{3}$. Pb levels in previous studies are as follows: in a rural area in Izmir, from 22.7 to $61 \mathrm{ng} / \mathrm{m}^{3}$ (Yatkin and Bayram, 2007), in a different urban area, between 53 and $88 \mathrm{ng} / \mathrm{m}^{3}$ (Samura et al., 2003). When the values are compared with the values obtained from these studies, the concentrations seem to be close to each other, although higher values are obtained in some seasons. The World Health Organization recommends the concentration of lead in the air of the city should be between $0.5-1 \mu \mathrm{g} / \mathrm{m}^{3}$ (RSHC, 2010). According to these limit values, the value of $\mathrm{Pb}$ at sample stations are below the limit.

Chromium concentrations were below the limit values for the measuring stations.

In this study, copper concentrations were found to be between 8.8 and $188.3 \mathrm{ng} / \mathrm{m}^{3}$. Concentration values of P4 and P5 stations were close to each other and lowest results are observed in these areas. P3 has relatively high $\mathrm{Cu}$ concentration. Cu emissions are released from brake wear (Sternbeck et al., 2002). Even, P3 is located next to 0-1 highway which has the highest traffic load within this study. Thus, it can be inferred that $\mathrm{Cu}$ emissions in this study is traffic related.

In the present study, cobalt concentration is observed to vary from 0.1 to $15.4 \mathrm{ng} / \mathrm{m}^{3}$ for $\mathrm{PM}_{2.5}$ and 0.2 to 16.3 for $\mathrm{PM}_{10}$ in sampling stations. Higher cobalt concentration was observed during spring season at entire sampling stations. Lower Co concentration was measured in the remaining seasons. Cobalt concentration rise in spring, may be explained by the long-range transportation of aerosols.

Yatkin and Bayram (2007) reported vanadium concentrations ranging from 7.6 to $12.8 \mathrm{ng} / \mathrm{m}^{3}$ in a rural area, in Izmir. In the following years, Samura et al. (2003) in urban areas of Bursa, found these values to be between 18 and $20.5 \mathrm{ng} / \mathrm{m}^{3}$. In this study, vanadium concentrations in collected samples ranged from 0.4 to $44.9 \mathrm{ng} / \mathrm{m}^{3}$. Vanadium concentration stayed in similar levels when compared with the previous studies.

$\mathrm{Al}, \mathrm{K}, \mathrm{Na}, \mathrm{Ca}, \mathrm{Mg}$ metals are naturally occurred elements. $\mathrm{Al}, \mathrm{Ca}, \mathrm{Fe}, \mathrm{K}$ metals are related to soil, $\mathrm{Na}$ metal is related to the sea salt (Yatkin and Bayram, 2007). When all sampling stations are considered, in the spring $\mathrm{Al}, \mathrm{K}, \mathrm{Na}, \mathrm{Ca}$, $\mathrm{Mg}$ concentrations were observed to have higher values than that in other seasons. This situation can be explained by the dust transportation from the Saharan Desert which 
occurred in March. Aerosols from dust storms expressed to include $\mathrm{Mg}, \mathrm{Al}, \mathrm{Si}, \mathrm{K}, \mathrm{Ca}$, and Fe elements in China (Fang et al., 2006).

$\mathrm{Pb}, \mathrm{Cu}, \mathrm{Cr}, \mathrm{Zn}, \mathrm{Cd}, \mathrm{V}$ were the most abundant metals in most of the stations. $\mathrm{Cu}$, and $\mathrm{Zn}$ are known as indicators of vehicle emissions. Moreover $\mathrm{Cr}, \mathrm{Cd}$, and $\mathrm{V}$ elements may occur even from industrial sources. In urban areas, road traffic is recognized as an important source of both particles and trace metals.

Revealing emissions from traffic includes identification of the sources and it is also important for constituting control measures. Road traffic include numerous potential sources of metals, e.g., combustion products from fuel and oil, wear products from tires, brake linings, bearings, coach and road construction materials, and resuspension of soil and road dust (Sternbeck et al., 2002). All these vehicular and non-vehicular sources lead diverse heavy metal emissions.

\subsection{Principal Component Analysis (PCA)}

Multivariate statistical factor analysis technique (PCA) was utilized to identify the main contributions of processes and estimate the possible sources of the particulate matters according to fractions ( $\mathrm{PM}_{2.5}$ and $\left.\mathrm{PM}_{10}\right)$. PCA was applied with a statistical package SPSS program (version 16) using Varimax Rotated Factor Matrix method. Metals and heavy metals were used as input variables. Chosen method produces factors that have high correlations with one smaller set of variables and little or no correlation with another set of variables (Srivastava et al., 2009; Đorđević et al., 2012).

75 samples of $\mathrm{PM}_{2.5}$ and 75 samples of $\mathrm{PM}_{10}$ were obtained. A total of 150 measurement results were run by the Principal Component Analysis (PCA) method for each particulate matter fraction $\left(\mathrm{PM}_{2.5}\right.$ and $\left.\mathrm{PM}_{10}\right)$ to determine the possible atmospheric particulate matter sources in the sampling sites. Total used elemental concentrations in PCA were for 13 pollutant species.

In the current PCA model study, the correlation matrix was used and obtained principal components were rotated by the method of Varimax. The varimax rotated results are shown in Figure 3 and Figure 4 for $\mathrm{PM}_{2.5}$ and $\mathrm{PM}_{10}$, respectively. The components whose absolute values of the principal component loadings were higher than 0.5 were used to estimate the factors which were possible pollutant sources.

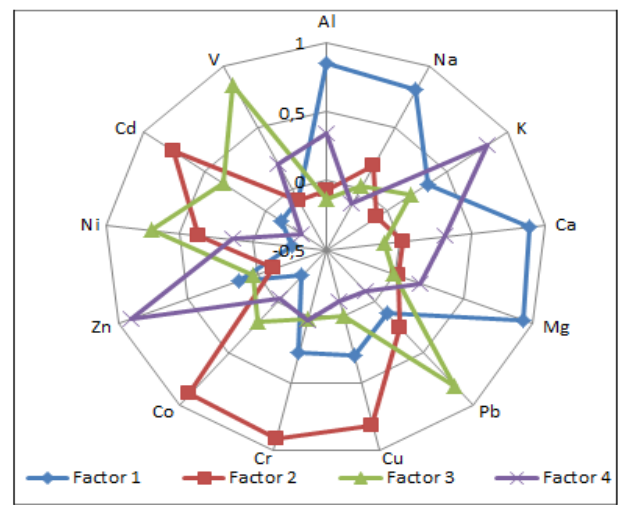

Figure 3. Rotated component matrix for $\mathrm{PM}_{2.5}$

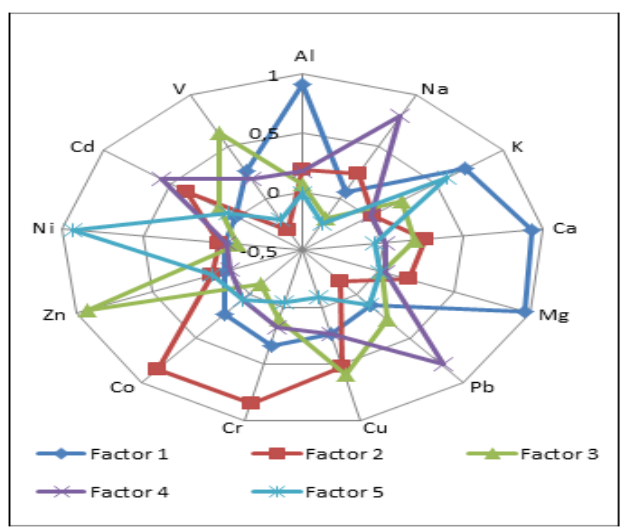

Figure 4. Rotated component matrix for $\mathrm{PM}_{10}$

Additionally, the contribution percentages of the variance values of the factors were given in the Table 3 . In this model study, components were extracted according to the criterion eigen vector $>1$. The applicability of the data for PCA analysis, data are tested considering KMO (KaiserMeyer-Olkin) test and Bartlett's test. Obtained results allowed to use the data for PCA analysis.

Table 3. Variance contribution values of the factors (components) according to particulate matter fractions

\begin{tabular}{cccccccc}
\hline \multirow{2}{*}{ Particulate Matter } & \multicolumn{7}{c}{ Variance Contribution (\%) } \\
\cline { 2 - 7 } & Total & 1. factor & 2. factor & 3. factor & 4. factor & 5. factor \\
\hline PM 2.5 & 82,277 & 31,323 & 27,435 & 16,09 & 7,429 & - \\
\hline PM 10 & 83,478 & 35,796 & 15,135 & 13,836 & 10,215 & 8,497 \\
\hline
\end{tabular}

The first factor of $\mathrm{PM}_{2.5}$ consists of $\mathrm{Al}, \mathrm{Na}, \mathrm{Ca}, \mathrm{Mg}$ and the first factor of $\mathrm{PM}_{10}$ consists of $\mathrm{Al}, \mathrm{K}, \mathrm{Ca}, \mathrm{Mg}$. $\mathrm{Al}, \mathrm{Ca}, \mathrm{Mg}$ and $\mathrm{K}$ are the elements related to Earth's crust, soil and mineral dusts. Especially, $\mathrm{Ca}$ and $\mathrm{Al}$ are the most known crustal and mineral dust elements (Lee and Hills, 2003). As three of these elements are the same for both $\mathrm{PM}_{2.5}$ and $\mathrm{PM}_{10}, \mathrm{Na}$ dominates the $\mathrm{PM}_{2.5}$ fraction and $\mathrm{K}$ dominates the $\mathrm{PM}_{10}$ fraction. $\mathrm{Na}$ is known as a one of the major elements from sea salt.
It is expressed that $\mathrm{Zn}, \mathrm{Ba}, \mathrm{Be}, \mathrm{Ca}, \mathrm{Cd}, \mathrm{Co}, \mathrm{Cr}, \mathrm{Cu}, \mathrm{Mn}, \mathrm{Ni}, \mathrm{Pb}$, $\mathrm{Se}, \mathrm{Sr}$ and Te elements are due to vehicular emissions (Srimuruganandam and Nagendra, 2011). In another study, it was reported that $\mathrm{Cu}, \mathrm{Zn}, \mathrm{Pb}$ were the abundant elements in vehicle emissions (Fang et al., 2003; Yatkin and Bayram, 2007). We can conclude that second factor is due to vehicle emissions for both of the fractions.

For $\mathrm{PM}_{2.5}$ the third factor was consisted of $\mathrm{Pb}, \mathrm{Ni}, \mathrm{V}$. $\mathrm{V}$ and $\mathrm{Ni}$ is known as the trace elements of fuel oil combustion (Samara and Voutsa, 2005; Yatkin and Bayram, 2007). Also, 
ships have significant particulate matter element source in terms of $\mathrm{V}$ and $\mathrm{Ni}$ (Colvile et al., 2001; Isakson et al., 2001). $\mathrm{Pb}$ can be seen due to the fuel combustion at ships. This factor can be considered as ship emissions. The last factor of $\mathrm{PM}_{2.5}$ is $\mathrm{K}$ and $\mathrm{Zn}$. It may be expected that $\mathrm{K}$ is originated along with the crustal elements but here it is not this case. In a study $\mathrm{Zn}, \mathrm{K}, \mathrm{Pb}, \mathrm{Br}$ were given as traffic originated elements (Marcazzan et al., 2001). Also, tire rubber abrasion was reported to be associated with $\mathrm{Zn}$ emission (Wang et al., 2005). This fourth factor of $\mathrm{PM}_{2.5}$ can be considered as traffic source. PCA results suggested that $\mathrm{PM}_{2.5}$ is mostly originated from both road traffic and marine traffic.

The third factor of $\mathrm{PM}_{10}$ is consisted of $\mathrm{Cu}, \mathrm{Zn}$ and $\mathrm{V}$ elements. $\mathrm{V}$ indicates fossil fuel combustion sources. $\mathrm{Cu}$ can also be released from vehicles, but it is not a combustion by-product. Copper is released due to braking activity. This emission latter can deposit on the road pavement. The forth factor is composed of $\mathrm{Na}, \mathrm{Pb}$ and $\mathrm{Cd}$ for $\mathrm{PM}_{10}$. $\mathrm{Pb}$ and $\mathrm{Cd}$ may be emitted from vehicle exhaust and industrial process. When the study area is considered,

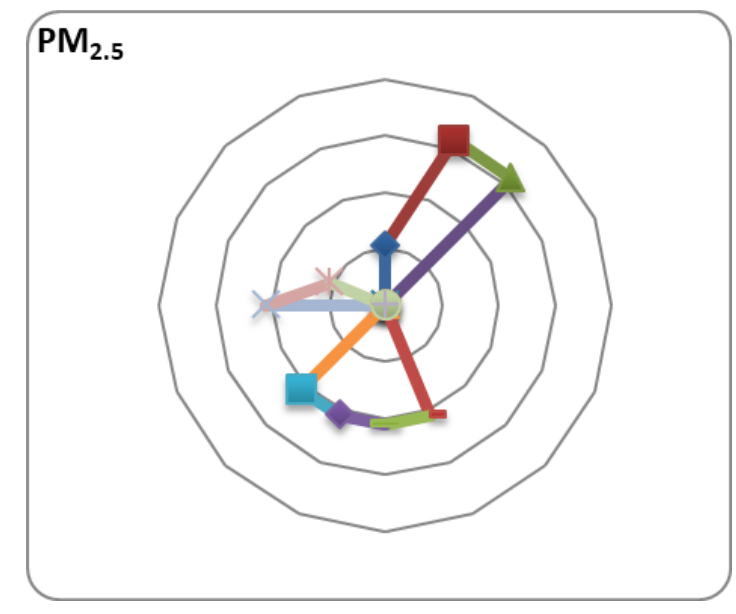

it can be inferred that this factor is representing exhaust emissions. The last factor is $\mathrm{K}$ and $\mathrm{Ni}$. These species are known to be the trace elements of biomass burnings.

In table 3, percentages of the total variance of the components were explained. For $\mathrm{PM}_{2.5}$ and $\mathrm{PM}_{10}$, explanation percentages are respectively $82.3 \%$ and $83.5 \%$. These values are considerably good at explaining the variances.

Effect of the wind on ambient $\mathrm{PM}_{2.5}$ and $\mathrm{PM}_{10}$ concentrations were evaluated through conditional probability function. In order to apply this function, measured concentrations were classified as polluted and unpolluted. A criterion was selected to differentiate the winds. Concentrations over upper-quartile were considered as polluted in this study.

The blown wind records were taken from 16 different wind sectors. Polluted wind count of each sector was divided by the total number of polluted wind count. Therefore, frequency of effective wind number was determined for each sector. Results are shown in Fig 5.

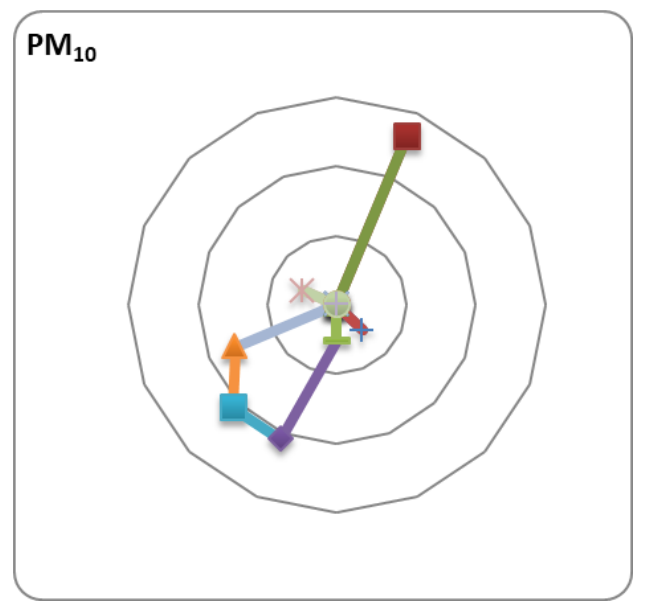

Figure 5. Relation of wind regime with $\mathrm{PM}_{2.5}$ and $\mathrm{PM}_{10}$

Higher $\mathrm{PM}_{2.5}$ and $\mathrm{PM}_{10}$ concentrations were observed when winds blew from southwesterly and northnortheasterly directions. Northerly and southerly winds had almost equal shares for $\mathrm{PM}_{2.5}$. However, southerly winds contributed to $\mathrm{PM}_{10}$ concentration at a higher rate. This result suggests different source profiles. Fine particles are mostly generated from combustion sources, whereas coarse particles are mechanically generated. Urban activities are present to the North-Northeast of the playgrounds, which yields fine particles. Winds blow over the Marmara Sea from southerly direction, pass over a short terrestrial area and reach to the playgrounds.

\subsection{Enrichment Factor (EF)}

The enrichment factor is an effective way of classifying the possible sources as to be either anthropogenic origin or natural origin. Enrichment factor is calculated as in Eq. 1.

$$
E F C=\frac{\left(C_{x} / C_{A l}\right)_{s a}}{\left(C_{x} / C_{A l}\right)_{C}}
$$

$C_{X}$ is the element concentration in particulate matter sample or earth crust and $\mathrm{C}_{\mathrm{Al}}$ is the concentration of $\mathrm{a}$ reference element. $\mathrm{Al}, \mathrm{Fe}, \mathrm{Ti}, \mathrm{Mg}$ are the elements which can be used for this purpose (Mateus et al., 2013). In this study, we chose Al as a reference element. Abundance of elements in earth's crust are present in previous studies. Based on the results of these studies, enrichment factor of particulate matters was calculated according to particulate matter fractions ( $\mathrm{PM}_{2.5}$ and $\left.\mathrm{PM}_{10}\right)$.

Enrichment factor of $<10$ represents that the trace metal has crustal origin and this element is defined as nonenriched. In contrast, $E F>10$ indicates that important proportion of an element has a non-crustal source. This is generally referred as anthropogenic source. These elements are considered as anomalously enriched elements (Mateus et al., 2013). Figure 6 shows the enrichment factors of PM fractions.

Enrichment factor of $\mathrm{Na}, \mathrm{K}, \mathrm{Ca}$, and $\mathrm{Mg}$ elements did not exceed the level of " 10 ". As a result of this evaluation, these elements are namely to be of crustal origin in either of the fractions. But enrichment factors of the remaining 
elements are above threshold except $\mathrm{Cr}$ at $\mathrm{PM}_{10}$. When enrichment factors of $\mathrm{PM}_{2.5}$ and $\mathrm{PM}_{10}$ fractions are compared, it is seen from Figure 5 that, $\mathrm{PM}_{2.5}$ fraction has higher factor values. According to this outcome, it can be

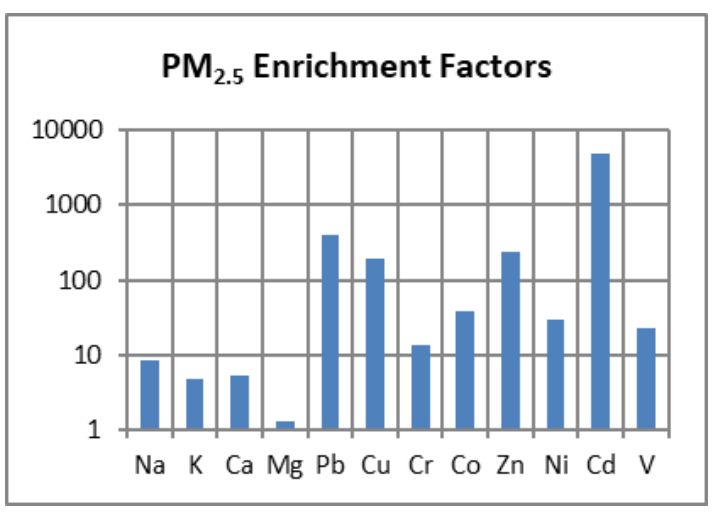

said that finer fraction is more related to anthropogenic sources than the coarse fraction. $\mathrm{Pb}, \mathrm{Cu}, \mathrm{Cr}, \mathrm{Co}, \mathrm{Zn}, \mathrm{Cd}, \mathrm{V}$, $\mathrm{Ni}$ elements are generally of anthropogenic origin. These results are also in agreement with PCA model results.

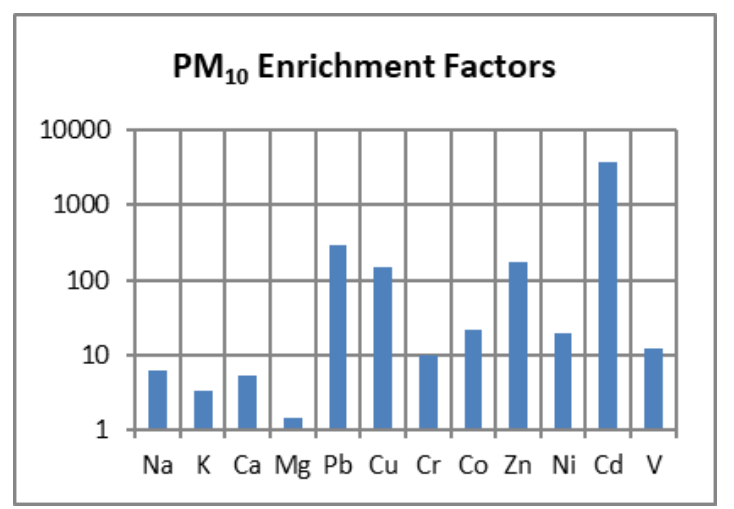

Figure 6. Enrichment Factors for $\mathrm{PM}_{2.5}$ and $\mathrm{PM}_{10}$

\section{Conclusions}

Particulate matter measurements were taken at 5 playgrounds in Istanbul over one-year period. There sampling sites existed near roads having dense traffic intensity. This is known to be a major source for urban area. Elemental compositions of the particulate matter showed that Istanbul ambient air was generally dominated by $\mathrm{Pb}$, $\mathrm{Cu}, \mathrm{Cr}, \mathrm{Zn}, \mathrm{Cd}, \mathrm{V}$ elements as known anthropogenic sources and $\mathrm{Al}, \mathrm{Na}, \mathrm{K}, \mathrm{Ca}, \mathrm{Mg}$ as known natural sources. Also, most of the concentrations were between the reported values in diverse urban areas, in Turkey. Obtained results were subject to principal component analysis and enrichment factor methods.

Four factors for $\mathrm{PM}_{2.5}$ and five factors for $\mathrm{PM}_{10}$ were determined by PCA method which has variance contributions of $82.3 \%$ for $\mathrm{PM}_{2.5}$ and $83.5 \%$ for $\mathrm{PM}_{10}$. Variance contribution percentages produced fine results for explaining the factor loadings of the components. Obtained PCA results indicated that traffic emissions and crustal dusts were the main sources of particulate matters in Istanbul ambient air. Enrichment factor analysis results showed that heavy metals were mostly anthropogenic enriched metals. One of the most known anthropogenic source for Istanbul is traffic originated emissions. Traffic emissions are a growing problem for Istanbul. As not yet observed, it is expected with the growing population that metal emissions could exceed the referred levels, in the near future. This will produce adverse outcomes for infants, children and elderly spending their time within the parks adjacent to roads with high traffic density.

\section{Acknowledgement}

This research has been supported by TUBITAK (The Scientific and Technological Research Council of Turkey). Project number is $108 \mathrm{Y} 173$.

\section{References}

Cheremisinoff N.P. (2002), Handbook of Air Pollution Prevention and Control, Butterworth-Heinemann, New York.
Colombi C., Angius S., Gianelle V. and Lazzarini M. (2013), Particulate matter concentrations, physical characteristics and elemental composition in the Milan underground transport system, Atmospheric Environment, 70, 166-178.

Colvile R.N., Hutchinson E.J., Mindell J.S. and Warren R.F. (2001), The transport sector as a source of air pollution, Atmospheric Environment, 35, 1537-1565.

D'Alessandroa A., Lucarelli F., Mandò P.A., Marcazzan G., Nava S., Prati P., Valli G., Vecchi R. and Zucchiatti A. (2003), Hourly elemental composition and sources identification of fine and coarse PM10 particulate matter in four Italian towns, Journal of Aerosol Science, 34, 243-259.

Demir G., Yigit S., Ozdemir H., Borucu G. and Saral, A. (2010), Elemental Concentrations of Atmospheric Aerosols and the Soil Samples on the Selected Playgrounds in Istanbul, Journal of Residuals Science and Technology, 7,123-130.

Đorđević D., Mihajlidi-Zelić A., Relić D., Ignjatović Lj., Huremović J., Stortini A.M. and Gambaro A. (2012), Size-segregated mass concentration and water soluble inorganic ions in an urban aerosol of the Central Balkans (Belgrade), Atmospheric Environment, 46, 309-317.

Fang G-C., Chang C-N., Chu C-C., Wu Y-S., Fu. P.P-C., Yang I-L., and Chen M-H. (2003), Characterization of Particulate, Metallic Elements of TSP, $\mathrm{PM}_{2.5}$ and $\mathrm{PM}_{2.5-10}$ Aerosols at a Farm Sampling Site in Taiwan, Taichung, Science of The Total Environment, 308, 157-166.

Fang G-C., Wu Y-S., Lin J-B, Lin C-K., Rau J-Y. and Huang S-H. (2006), Characterization of Atmospheric Particulate and Metallic Elements at Taichung Harbor near Taiwan Strait during 2004-2005, Chemosphere, 63, 1912-1923.

Finlayson-Pitts B.J. and Pitts J.N. (1986), Atmospheric Chemistry: Fundamentals and Experimental Techniques, Wiley, New York.

Giles L.V. and Koehle M.S. (2014), The health effects of exercising in air pollution, Sports Medicine, 44, 223-249.

Hetland R.B., Cassee F.R., Refsnes M., Schwarze P.E., Låg M., Boere A.J.F. and Dybing E. (2004), Release of Inflammatory Cytokines, Cell Toxicity and Apoptosis in Epithelial Lung Cells after Exposure to Ambient Air Particles of Different Size Fractions, Toxicology in Vitro, 18, 203-212. 
IPCC, (2001), Intergovernmental Panel on Climate Change, Third Assessment Report. In: Climate Change 2001: Synthesis Report, Cambridge University Press, Cambridge.

Isakson J., Persson T.A. and Lindgren E.S. (2001), Identification and assessment of ship emissions and their effects in the harbour of Göteborg, Sweden, Atmospheric Environment, 35, 3659-3666.

Kesavachandran C.N., Kamal R., Bihari V., Pathak M.K. and Singh A. (2015), Particulate matter in ambient air and its association with alterations in lung functions and respiratory health problems among outdoor exercisers in National Capital Region, India, Atmospheric Pollution Research, 6, 618-625.

Koçak M., Mihalopoulos N. and Kubilay N. (2009), Origin and source regions of $\mathrm{PM}_{10}$ in the Eastern Mediterranean atmosphere, Atmospheric Research, 92, 464-474.

Kuzu S.L., Saral A., Demir S., Summak G. and Demir G. (2013), A detailed investigation of ambient aerosol composition and size distribution in an urban atmosphere, Environmental Science and Pollution Research, 20, 2556-2568.

Lee Y.C. and Hills P.R. (2003), Cool Season Pollution Episodes in Hong Kong, 1996-2002, Atmospheric Environment, 37, $2927-$ 2939.

Marcazzan G.M., Vaccaro S., Valli G. and Vecchi R. (2001), Characterisation of PM10 and PM2.5 particulate matter in the ambient air of Milan (Italy), Atmospheric Environment, 35, 4639-4650.

Mateus V.L., Monteiro I.L.G., Rocha R.C.C., Saint' Pierre T.D. and Gioda A. (2013), Study of the chemical composition of particulate matter from the Rio de Janeiro metropolitan region, Brazil, by inductively coupled plasma-mass spectrometry and optical emission spectrometry, Spectrochimica Acta Part B: Atomic Spectroscopy, 86, 131136.

Merešová J., Florek M., Holý K., Ješkovský M., Sýkora I., Frontasyeva M.V., Pavlov S.S. and Bujdoš M. (2008), Evaluation of elemental content in air-borne particulate matter in low-level atmosphere of Bratislava, Atmospheric Environment, 42, 8079-8085.

Ozdemir H., Borucu G., Demir G., Yigit S. and Ak N. (2010), Examining the Particulate Matter (PM2.5 ve PM10) Pollution on the Playgrounds in Istanbul, Ekoloji, 19, 72-79.

RSHC, (2010), Refik Saydam Hygiene Center Presidency, Department of Environmental Health Research, http://www.rshm.saglik.gov.tr/hki/pdf/hava.pdf

Samara C. and Voutsa D. (2005), Size distribution of airborne particulate matter and associated heavy metals in the roadside environment, Chemosphere, 59, 1197-1206.

Samura A., Al-Agha O. and Tuncel S.G. (2003), Study of Trace and Heavy Metals in Rural and Urban Aerosols of Uludağ and Bursa (Turkey), Water, Air and Soil Pollution:Focus, 3,111-129.

Seinfeld J.H. and Pandis S.N. (2006), Atmospheric Chemistry and Physics, From Air Pollution to Climate Change, Second Edition, John Wiley \& Sons, Inc., New Jersey.

Shah M.H. and Shaheen N. (2007), Statistical analysis of atmospheric trace metals and particulate fractions in Islamabad, Pakistan, Journal of Hazardous Materials, 147, 759-767.

Srimuruganandam B. and Nagendra S.M.S. (2011), Chemical characterization of $\mathrm{PM}_{10}$ and $\mathrm{PM}_{2.5}$ mass concentrations emitted by heterogeneous traffic, Science of The Total Environment, 409, 3144-3157.
Srivastava A., Gupta S. and Jain V.K. (2009), Winter-time size distribution and source apportionment of total suspended particulate matter and associated metals in Delhi, Atmospheric Research, 92, 88-99.

Sternbeck J., Sjödin Å. and Andréasson K. (2002), Metal emissions from road traffic and the influence of resuspension-results from two tunnel studies, Atmospheric Environment, 36, 4735-4744.

Viana M., Querol X., Alastuey A., Gil J.I. and Menéndez M. (2006), Identification of PM sources by principal component analysis (PCA) coupled with wind direction data, Chemosphere, 65, 2411-2418.

Wang X., Sato T., Xing B., Tamamura S. and Tao S. (2005), Source identification, size distribution and indicator screening of airborne trace metals in Kanazawa, Japan, Journal of Aerosol Science, 36, 197-210.

WHO, (2003), Climate Change and Human Health-Risks and Responses, Summary, Geneva.

WHO, (2007), Urban Air Pollution and Health in a Warming World, World Bank, Washington, D.C.

WHO, (2013), Health Effects of Particulate Matter, Policy Implications for Countries in Eastern Europe, Caucasus and Central Asia, Copenhagen.

Yatkin S. and Bayram A. (2007), Elemental Composition and Sources of Particulate Matter in the Ambient Air of a Metropolitan City, Atmospheric Research, 85, 126-139.

Young L.H. and Wang C.S. (2002), Characterization of $n$-alkanes in $\mathrm{PM}_{2.5}$ of Taipei aerosol, Atmospheric Environment, 36, 477482. 